\title{
MOSS FLORA OF THE AINOV ISLANDS, BARENTS SEA
} ФЛОРА МХОВ АЙНОВЫХ ОСТРОВОВ (БАРЕНЦЕВО МОРЕ)

\author{
MikHAil N. KOZHIN ${ }^{1,2}$, Olga A. BELKinA ${ }^{3}$, AleKSEY Yu. LiKHACHEV ${ }^{3}$ \& ElenA A. IGNATOVA ${ }^{1}$ \\ МИХАИЛ Н. КОЖИН ${ }^{1,2}$, ОЛЬГА А. БЕЛКИНА ${ }^{3}$, АЛЕКСЕЙ Ю. ЛИХАЧЕВ ${ }^{3}$, ЕЛЕНА А. ИГНАТОВА $^{1}$
}

Abstract

\begin{abstract}
The bryoflora of the Ainov Islands is characterized as poor and incomplete; in total 66 species with 3 infraspecific taxa were found here. It is the lowest number of species known from island floras of the European Subarctic due to the small area, low habitat diversity and vast bird rookeries. In 1960-1980s huge colonies of Larus argentatus and Larus marinus populated the Islands thus provoking the process of ecosystem organic enrichment. As a result, Pleurozium schreberi, Paludella squarrosa and Plagiomnium elatum disappeared, Dicranum scoparium, Hylocomium splendens, Helodium blandowii, Rhytidiadelphus squarrosus declined in occurrence in tundra-like communities and swamps, epilithic mosses became very rare and low-numbered. All the evidence taken into account, low resistance of mosses to intense bird-influenced eutrophication was observed.
\end{abstract}

Резюме

Бриофлора мхов Айновых островов характеризуется бедностью и неполнотой; всего было обнаружено 66 видов и 3 разновидности листостебельных мхов. Среди островных флор европейской Субарктики она отличается наименьшим числом видов, что обусловлено малой площадью островов, низким разнообразием местообитаний и влиянием крупных колоний гнездящихся птиц. В 1960 1980-х годах на островах появились большие колонии морских и серебристых чаек, жизнедеятельность которых привела к сильной эвтрофикации островных экосистем. Из флор островов исчезли Pleurozium schreberi, Paludella squarrosa и Plagiomnium elatum, значительно снизили свое участие виды тундрообразных сообществ и болот - Dicranum scoparium, Hylocomium splendens, Helodium blandowii и Rhytidiadelphus squarrosus. Поскольку скалы сильно эвтрофицированы птицами, эпилитных видов на островах мало и они крайне редки. Отмечена низкая устойчивость мхов к интенсивной орнитогенной эвтрофикации.

KEYWORDS: bryophyte flora, island biogeography, bird influence, ornithogenic vegetation, Larus argentatus, Larus marinus, Kandalaksha State Nature Reserve, Kola Subarctic, Murmansk Province

\section{INTRODUCTION}

The Ainov Islands (Finnish: Heinäsaari) are situated in the eastern part of the Varanger Fjord Bay of the Barents Sea (Murmansk Province, Russia); they comprise Bolshoi Ainov Island (Finnish: Heinäsaaret) and Malyi Ainov Island (Finnish: Pieni Heinäsaari). An intricate pattern of natural conditions as well as several changes in human exploitation in the territory made it a place of considerable interest for naturalists. On the one hand, the Ainov Islands are famous for vast rookeries of ravishing Atlantic puffin Fratercula arctica (Linnaeus, 1758), commonly known as 'sea parrots' (Pearson, 1904). On the other hand, this territory belonged to different countries during the $20^{\text {th }}$ century. In 1920-1944 it was part of Finland, meanwhile the Islands were thoroughly studied by Finnish bot- anists. Ernst Häyren (1955) and Kaarlo Linkola collected the first specimens of mosses from the Ainov Islands $(\mathrm{H})$. After the Second World War, the Petsamo Province was ceded to the Soviet Union and already in 1947 the Ainov Islands were included into Kandalaksha Nature Reserve (former Sem Ostrovov Reserve). N.S. Parfentyeva, a staff of Moscow State University, investigated the flora and vegetation of both islands in 1958 and 1959. The moss collection was mainly determined by Moscow geobotanist S.N. Tyuremnov. Among the preliminary botanical data the first list of mosses containing 26 species was published (Parfentyeva \& Breslina, 1969).

Ecosystems of the Ainov Islands altered drastically during the $20^{\text {th }}$ century due to negative influence of various marine bird colonies nesting there (Tatarinkova, 1967,

1 - Lomonosov Moscow State University, Biological Faculty, Geobotany Dept., Leninskie Gory Str. 1-12, Moscow 119234 Russia - Россия, 119234, Москва, Ленинские Горы, д. 1 стр. 12, Московский государственный университет, биологический факультет, кафедра геоботаники; е-mails: mnk umba@mail.ru, arctoa@list.ru

2 - Россия 184042, Мурманская область, Кандалакша, ул. Линейная, д. 35, Кандалакшский государственный природный заповедник - Kandalaksha State Nature Reserve, Lineynaya str. 35, Kandalaksha, Murmansk Province, 184042 Russia

3 - Polar Alpine Botanical Garden annd Institute of the Kola Science Center of RAS, Kirovsk, Murmansk Province, 184256 , Russia - Россия, 184256, г. Кировск, Мурманская область, Полярно-альпийский ботанический сад-институт им. Н.A. Аврорина Кольского НЦ РАН; e-mail: belkina_07@list.ru 


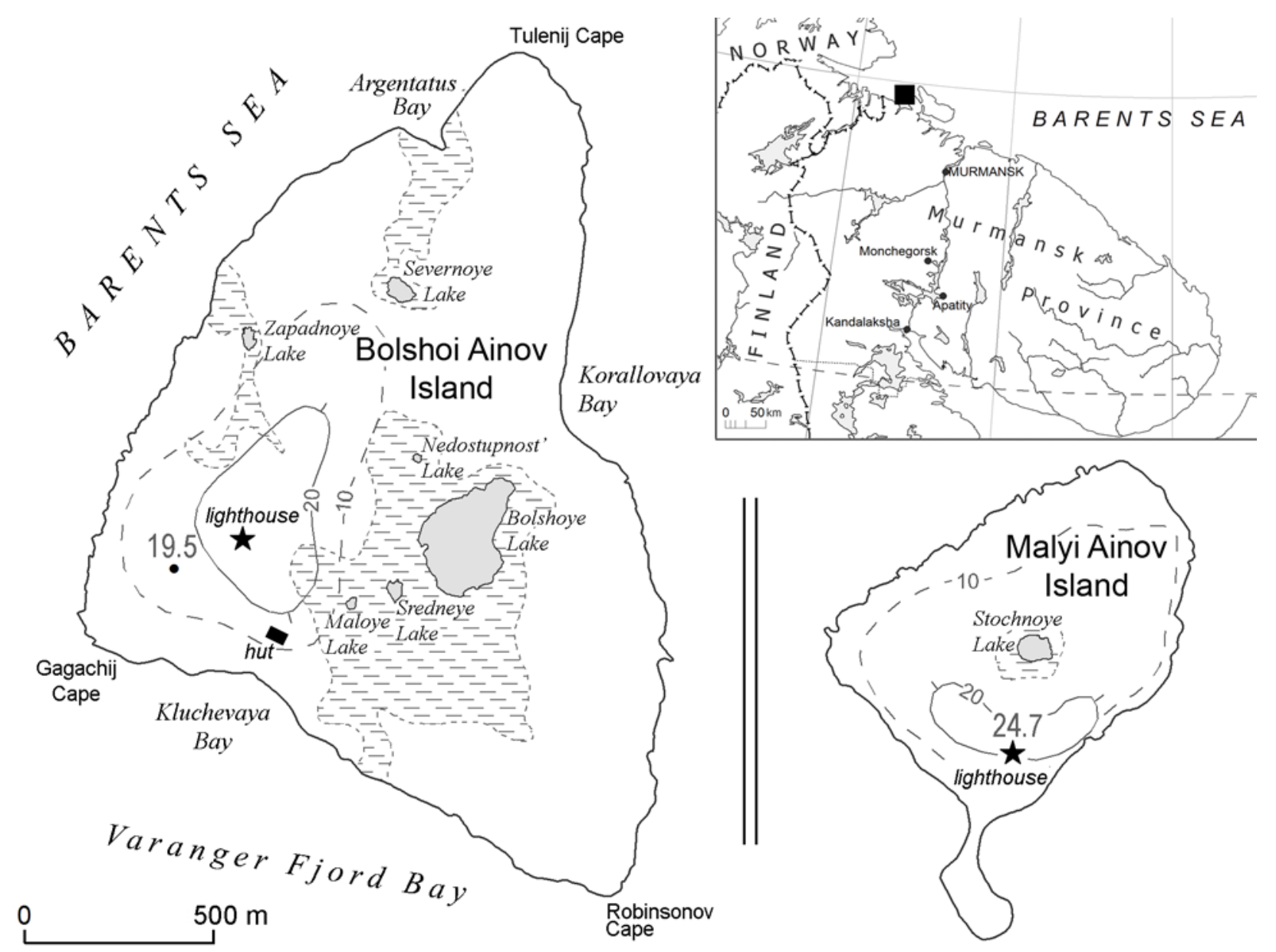

Fig. 1. Study area: Ainov Islands, Varanger Fjord Bay of the Barents Sea.

1975; Ivanenko, 2013a). However, changes in vegetation and flora composition were not studied for more than half of a century. Our work attempts to describe the temporary moss flora composition and to estimate its retrospective changes.

\section{STUDY AREA}

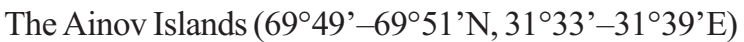
are located above the Arctic Circle near the western part of the Murman Coast of the Barents Sea (Fig. 1). Bolshoi Ainov Island occupies about $207 \mathrm{ha}$; it is $2.2 \mathrm{~km}$ long and $1.4 \mathrm{~km}$ wide, and a summit surface is about $15-20 \mathrm{~m}$ above sea level. There are five small shallow lakes in its central and northwestern parts. Malyi Ainov Island is located 1.5 $\mathrm{km}$ southeast from the latter. It has an area of $59 \mathrm{ha}$, length of $1.3 \mathrm{~km}$ and width of $1.4 \mathrm{~km}$. The island is characterized by a summit surface of about $20 \mathrm{~m}$ above sea level with a depression and a small lake in the center. The minimal distance to the mainland is $3.5 \mathrm{~km}$.

The geological structure of the Islands is slightly similar to that of the Rybacy and Sredny Peninsulas. They are composed of Paleozoic arkose sandstone, clay slate, conglomerate, limestone, and dolomite and overlapped by Quaternary soft sediments. The summit plains constitute the main part of islands; they are covered by heavy layer of dry peat (depth about 1.0-1.5 m). Sandy ridges occur on a periphery of the Islands and represent an ancient offshore bar. Coastal line is slightly indented, low-sloped with stony, rocky outcrops or rocky terraced parts.

The study area features Subarctic climate with long soft winter and cool summer. The Norwegian Current prolonged into the Nordcapp Current provides a considerable climate impact (Yakovlev, 1961). In winter heat is released from the ocean to the overlying air masses generally flowing northeasterly and thereby warming the coastal regions. The nearest weather station is situated $18 \mathrm{~km}$ northeast from the Islands, in Vayda-Guba Settlement (ID 22003). The station has over one hundred years period of records. Mean annual temperature is $1.4{ }^{\circ} \mathrm{C}$. The coldest month is February with mean temperature of $-6.2{ }^{\circ} \mathrm{C}$ while the temperature of the warmest month July - is $10.2^{\circ} \mathrm{C}$. Annual precipitation equals ca. $470 \mathrm{~mm}$, mostly occurring in summer and autumn (Novakovskiy \& Elsakov, 2014). Air humidity is constant throughout the year.

\section{BIRD ROOKERIES AND THEIR INFLUENCE}

The Ainov Islands are essential for marine bird nesting on the Murman Coast due to both reservation conditions (Häyren, 1927; Gerasimova, 1958) and isolation. 

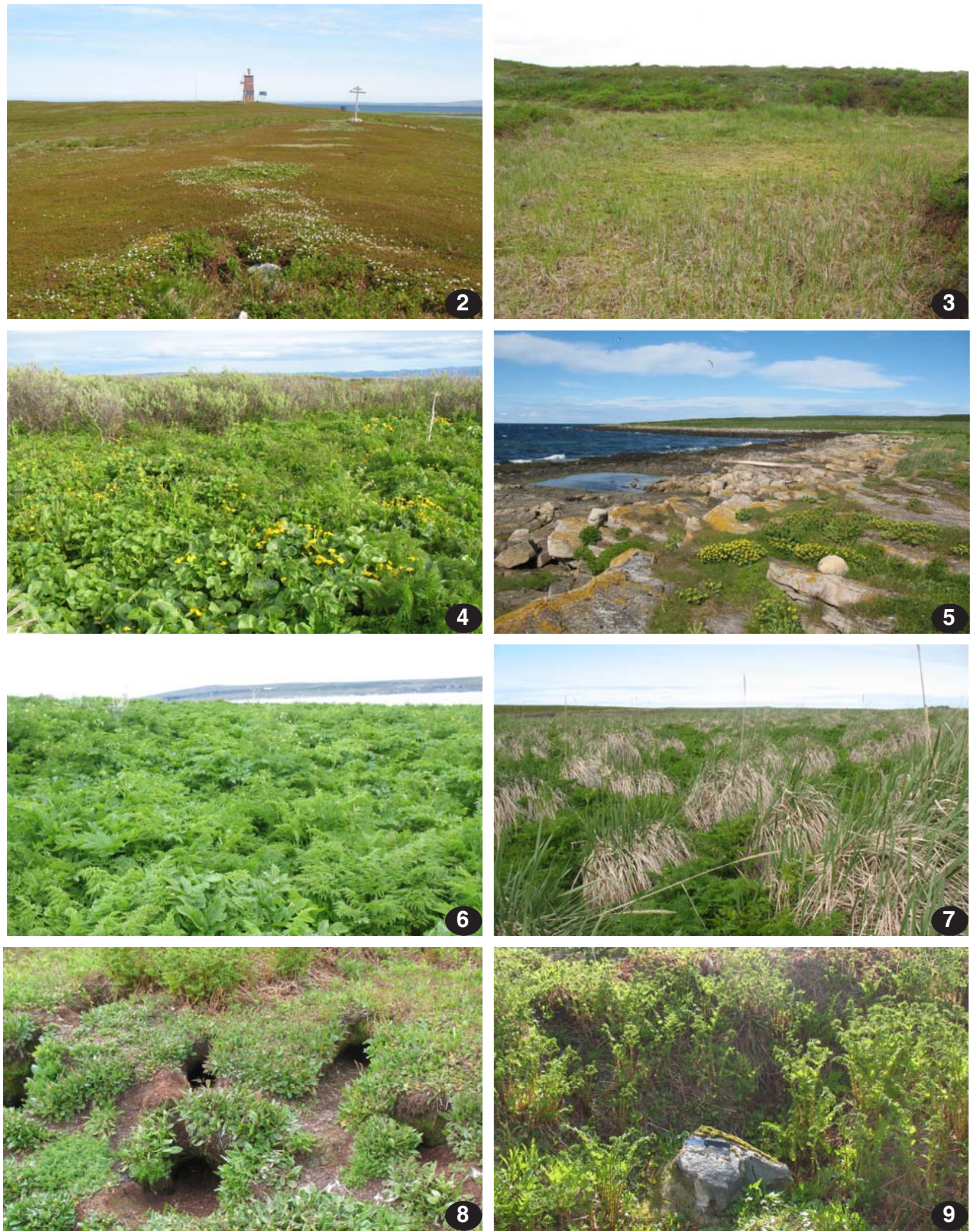

Figs. 2-9. The Ainov Islands. 2. Tundra-like community with domination of Empetrum nigrum and Rubus chamaemorus; 3. Sedge (Carex aquatilis) swamp with Sphagnum squarrosum and S. riparium; 4. Eutrophic swamp with Caltha palustris, Angelica archangelica and Anthriscus sylvestris (forefront) and willow (Salix glauca) stand (second place); 5. Rocky coastal meadow with Rhodiola rosea, Honckenya peploides, Festuca richardsonii and Sanionia uncinata; 6 . Tallgrass community of Angelica archangelica and Anthriscus sylvestris with Plagiomnium ellipticum, Sciuro-hypnum reflexum and S. curtum; 7. The lyme grass (Leymus arenarius) tussock fields; 8. Groups of Rumex acetosa s.1. near the burrow entrances in the Atlantic puffin rookery; 9 . A stone with epilithophyte mosses among fern (Dryopteris expansa) meadow. 
Common eider Somateria mollissima (Linnaeus, 1758), European herring gull Larus argentatus Pontoppidan, 1763, great black-backed gull Larus marinus Linnaeus, 1758, and Atlantic puffin are the most numerous marine birds on the Islands (Ivanenko, 2013a). The bird population level as well as species dominance have experienced several changes since the $19^{\text {th }}$ century.

In 1928 Walther Emeis, director of Flensburg Museum of Natural History (Germany), visited the Islands and recorded vast rookeries of the Atlantic puffin. The population level was estimated at more than 40000 individuals comprising the majority of the Islands birds (Emeis, 1929). Although Atlantic puffins were observed in various parts of the Islands, the rookeries were predominantly found on coastal slopes. The puffins were observed to nest in burrows in thick peat layer or rarely in crevices of the coastal rocks. The burrow entrances were clearly visible as they were trampled down by the birds and overgrown by rampant Tripleurospermum hookeri Sch. Bip. As a result, the puffin rookeries intensively transformed the plant cover on the slopes while the summit plains, swampy depressions and lakes were less disturbed as they were seldom used by the puffins for living, resting and eating. At the same time about 5000 European herring gulls and 2000 great black-backed gulls were reported to have populated the Islands (Emeis, 1929).

In the middle of the $20^{\text {th }}$ century T.D. Gerasimova (1951) registered a decrease in puffin population on the Islands. In 1947 approximately 23000 Atlantic puffins inhabited the Islands, but in 1951 their number halved. According to Gerasimova (1951), the population decrease was inflicted by sea gulls, since numerous dead nestling and adult puffins were found, as well as cases of sea gull mobbing were recorded. Notably, in July 1951 the puffins were estimated to comprise $40 \%$ of gull food ration. Furthermore, retraction of fish resources might had also contributed to the population level decrease (Ivanenko, 2013a). At the same time, the colonies of European herring gull and great black-backed gull were estimated at 2500 and 1400 individuals respectively (Gerasimova, 1958).

In 1960s the population level of sea gulls increased rapidly on the Islands; in 1968 it amounted to 14500 individuals (Bolshoi Ainov: 7000 - Larus argentatus, 5000 - Larus marinus; Malyi Ainov: 1200 and 1300 respectively) with approximate population density of over 50 individuals per ha (Tatarinkova, 1970, 1975). Extremely high population level had a considerable impact on all components of island ecosystems. Excretory activity of gulls deeply affected the plant communities due to fertilization of soil with plant nutrients. A special investigation showed that 280-350 t of guano fall on the surface of Bolshoi Ainov Island per year (Tatarinkova, 1975). In addition, bird physical impact was considerable, as gulls actively trampled places near nests, rest places and observing sites.
Moreover, gulls torn away grasses and pieces of peat during quarrels between neighbors. As a result entire sights were destroyed and, therefore, the vegetation cover as a whole was drastically transformed by gull rookeries (Tatarinkova, 1975). The communities with domination of cloudberry (Rubus chamaemorus L.) and crowberry (Empetrum hermaphroditum Hagerup and E. nigrum L.) had sites with bare peat, meadows and thickets of ornithophilous plant species, e.g., Tripleurospermum hookeri and $\mathrm{Me}$ landrium lapponicum (Simmons) Kuzen. (Tatarinkova, 1975). Changes in vegetation were evident in all parts of the Islands. On the whole the island ecosystems experienced a complete eutrophication.

In subsequent years the general bird population level declined gradually. Its probable cause was shortage of fish as a main forage resource due to industrial overfishing in 1980s (Ivanenko, 2013a). In 2002 population level of birds amounted to 1700 European herring gulls, 1160 great black-backed gulls, and 600 Atlantic puffins (Ivanenko, 2013b). Since 2000s the rookeries of greylag goose Anser anser (Linnaeus, 1758) were recorded on the Islands (Tatarinkova et al., 2007), particularly in 2010, the population level of the goose reached 500 individuals. They nested only among lyme grass (Leymus arenarius (L.) Hochst.) tussocks and willow thickets (Ivanenko, 2013b).

Thus, since the early $20^{\text {th }}$ century, population level of birds and dominated species have varied intensively. In different periods the bird influence led to multiple transformations of vegetation cover.

\section{VEGETATION}

The Ainov Islands are situated in southern hypoarctic tundra subzone (Safronova et al., 1999). The vegetation of the neighboring area, namely the Rybachy and the Sredny Peninsulas, is characterized in detail (Kalela, 1939). However, the Islands plant cover differs from the mainland (Parfentyeva, 1969; Georgievskij, 1980).

Tundra-like communities (Fig. 2) cover about $40 \%$ of the Islands area (Tatarinkova, 2011) and are represented by crowberry dominated heath with cloudberry and fern on well drained peat soil. The communities are different from the mainland tundra in various respects. First, they predominantly occur on peatlands with the layer ordinarily of about $1 \mathrm{~m}$ thick formed in mild marine climate and high humidity conditions. Second, they do not usually consist of typical dwarf birches and tundra dwarf shrubs, e.g. Loiseleuria procumbens (L.) Desv., Phyllodoce caerulea (L.) Bab. and Diapensia lapponica L. (Breslina, 1971). The island flat surface is covered by crowberry and crowberry - cloudberry dominated communities. They are monotonous and poor in species. Mosses and lichens occur very rarely among herbs and dwarf shrubs. The slight slopes are occupied by complex vegetation of crowberry cloudberry heath and buckler fern (Dryopteris expansa (C. Presl) Fraser-Jenk. \& Jermy) communities. Melandrium lapponicum, Trientalis europaea L. and Rumex acetosa L. s.l. sporadically grow here. Rampant meadows with 
domination of Dryopteris expansa sporadically occur among dwarf shrub communities.

Swamps are widespread on the Islands; they occupy lake depressions, low sites of ancient sea-shore terraces and hollows among small hills. They are mostly represented by eutrophic and transitional swamps with domination of Carex aquatilis Wahlenb., Eriophorum angustifolium L. and Salix glauca L. (Fig. 2) Eutrophic tall grass swamps are abundant on the inundated lake shores. Their vegetation includes rampant Angelica archangelica L., Stellaria crassifolia L. and Caltha palustris L. s.l. above $1 \mathrm{~m}$ high (Fig. 4) and continuous cover of Sphagnum squarrosum and $S$. riparium. Cushions of Carex aquatilis and Comarum palustre L. grow in shallow water.

Transitional swamps occur sporadically. The herb layer is formed by Carex aquatilis, Eriophorum angustifolium, Carex rostrata Stockes, Menyanthes trifoliata L., Calamagrostis neglecta (Ehrh.) Gaertn., B. Mey. \& Schreb. s.1., and Equisetum palustre L. The moss cover diversity is limited and represented by Sphagnum squarrosum, Plagiomnium ellipticum, Aulacomnium palustre, Calliergon cordifolium, and Helodium blandowii.

Dryed mesotrophic fens and raised bogs are not frequent on the Islands. They are characterized by small hummock surface and vegetation cover featuring both meadow and tundra traits. Chamaenerion angustifolium (L.) Scop., Leymus arenarius and Dryopteris expansa usually grow in hollows. Hummock tops are covered by crowberry communities with cloudberry; however, Rumex aceto$s a$, as an illustrative ornithophilous species, is permanently present in the bogs. There are numerous sites with trampled vegetation and rampant weeds, for instance Tripleurospermum hookeri, Rumex acetosa s.1., Melandrium lapponicum, Valeriana sambucifolia J.C. Mikan, and Cochlearia officinalis L. s.l. The hummocks have probably formed on the place of old gull nests. As a result, the sphagnous cover degraded, while the grass sod spread across the bogs (Breslina, 1987).

Willow thickets cover less than $10 \%$ of the Islands area (Tatarinkova, 2011); they are present in water-logged communities on the margins of the swamps, in lake depressions and among peat hummocks. Salix glauca about $1 \mathrm{~m}$ high is the main component of dense thickets added by Salix phylicifolia about $1.8 \mathrm{~m}$ high (Fig. 4). The herb layer is formed by conspicuous tall grasses (e.g., Anthriscus sylvestris (L.) Hoffm., Angelica archangelica), swamp herbs (e.g., Carex aquatilis, Rubus chamaemorus, Menyanthes trifoliata, Ranunculus repens) and short grasses (e.g., Trientalis europaea and Bistorta vivipara). The groups of Calamagrostis langsdorffii (Link) Trin. grow occasionally on tops of peat hummocks among flooded hollows.

Coastal meadows are predominantly represented by narrow belts on slight slope benches of bays. Sparse halophyte communities of Mertensia maritima (L.) Gray, Honckenya peploides (L.) Ehrh., Atriplex sp., and Cochlearia officinalis L. s.l. occur throughout sandy or stony supralit- toral zone, while Festuca richardsonii Hook., Poa pratensis L. s.l., and Sanionia uncinata cover boulders with a sward. Solitary tufts of Puccinellia coarctata Fernald \& Weath. and Rhodiola rosea L. s.l. grow among fissures and crevices of coastal outcrops (Fig. 5). Pure dense thickets of Leymus arenarius about $1 \mathrm{~m}$ high are common to sandy windless bays. Tallgrass communities of Leymus arenarius, Angelica archangelica, and Anthriscus sylvestris, Plagiomnium ellipticum, P. medium, Sciuro-hypnum reflexum, and $S$. curtum are widespread on the ancient sea-shore terrace usually with slightly sodded boulders (Fig. 6). Short grass forb meadows are confined to the lower parts of the coastal slopes. These diverse communities form a dense stand of about 0.6-0.7 m of forbs (e.g., Alchemilla murbeckiana Buser, Allium schoenoprasum L., Geranium sylvaticum L., Valeriana sambucifolia, Veronica longifolia L., Trollius europaeus), grasses (e.g., Festuca richardsonii, Poa pratensis) and moss cover of Sciuro-hypnum starkei, S. reflexum, and Rhytidiadelphus squarrosus.

The lyme grass (Leymus arenarius) tussock fields (Fig. 7) are a striking trait of the Island plant cover known as the 'grass mounds' since the early $20^{\text {th }}$ century (Pearson, 1903). Besides, they are locally spread on islands of the Barents and the White Seas (Tatarinkova, 2011). The tussock communities occupy about $20 \%$ area of Bolshoi Ainov Island and commonly occur on slight slopes near the bays, plains and hollows with nonmoving water. The tussocks, as a specific life form of Leymus arenarius, have a diameter of $0.5-0.7 \mathrm{~m}$. There are a lot of moist grassland litters in gaps between tussocks where Brachythecium salebrosum, Plagiothecium denticulatum, Sanioinia uncinata, Pohlia nutans, and Warnstorfia fluitans sparsely grow.

Rock outcrops and cliffs rarely occur in the inner parts of the Islands. Usually they are represented by rock terraces up to $3 \mathrm{~m}$ high with flag-like structure and numerous crevices. Solitary groups of Dryopteris expansa, Gymnocarpium dryopteris, Chamaenerion angustifolium, Pohlia cruda, and Bryum spp. vegetate on moist peat and fine soil among rock shelves and crevices.

Ornithogenic vegetation is widespread on the Islands (Breslina, 1987). Primary vegetation of Cochlearia officinalis s.1. and Puccinellia coarctata gradually populates coastal bare rocks as they are fertilized by birds. Secondary ornithogenic vegetation is frequently observed in Island plant cover; it is represented by rampant groups of Tripleurospermum hookeri, Rumex acetosa s.l., and Melandrium lapponicum ca. $0.5 \mathrm{~m}$ high in contemporary bird rookeries (Fig. 8). The sites of former colonies are overgrown with Chamaenerion angustifolium and Rubus chamaemorus (Tatarinkova, 1967).

Henry John Pearson (1904), a British ornithologist and naturalist, numerously visited the Islands in the late $19^{\text {th }}$ early $20^{\text {th }}$ centuries. He paid special attention to exuberant vegetation and suggested that the abundant plant cover was the result of intensive fertilization by numerous nesting birds. Consequently, bird influence on the ecosystem has been known for more than a century. 


\section{MATERIALS AND METHODS}

The research material was collected during the complex expedition to the Ainov Islands on 16-22 June, 2010. O.A. Belkina conducted field work throughout the timeframe of the expedition on the Bolshoi Ainov Island and on June 16 on the Malyi Ainov Island. Bryological research took place during the bird nesting period; therefore, we could not visit some areas (e.g., between the Bolshoye and Nedostupnost Lakes). 370 specimens of mosses from 95 plots were collected and deposited in the KPABG and KAND.

In 2011 and 2015 M.N. Kozhin revised 91 herbarium specimens of N.S. Parfentyeva's collection (KAND) and submitted the information to "Herbarium specimens of Russian mosses" (www.arctoa.ru).

\section{LIST OF SPECIES}

Species are annotated with frequency (Un - unique; Rar - rare; Sp - sparse; Fr - frequent; Com - common), ecology, associated species (if they were noticed), gametangium $(\mathrm{G}+)$, sporophyte $(\mathrm{S}+)$ or vegetative reproduction $(\mathrm{P}+)$ presence. Names of the islands are listed shortly: $\mathrm{M}$ - Malyi Ainov Island, B - Bolshoi Ainov Island. For occasional species precise descriptions of localities and geographical coordinates (WGS-84) are given. The new taxa for the Ainov Islands include 46 species marked by '*'. We have followed the nomenclature of Ignatov, Afonina, Ignatova et al. (2006) with latest additions.

*Amblystegium serpens - M: rock ridge in southern part of the island, in a crack of a wet rocky wall; Rar. - B: outcrops and crevices of coastal rocks, cement foundation of the lighthouse, wooden planks of a well, on eroded soil of tracks, shoots of willow in bush community. Usually grows solely without other species; Fr, S+.

Aulacomnium palustre - B: inner part of the island, upper part of sedge-sphagnum, cotton grass and herbs-sphagnum swamps, willow thickets with sedges, turf mound among tundra. The species grows as an addition to turfs of Sphagnum spp., Paludella squarrosa, Plagiomnium elatum, P. ellipticum, Helodium blandowii, Dicranum scoparium and in pure mats as well; $\mathrm{Fr}, \mathrm{G}+, \mathrm{P}+$.

* _ var. imbricatum - B: vicinities of Severnoye Lake: in sedgecloudberry-sphagnum swamps and on the wooden roof of a blindage overgrown with vascular plants, mosses and nitrophilous algae and covered with massive quantities of bird guano; sedge-moss swamps near Maloye, Bolshoye and Srednee Lakes, with Lophozia sp., Helodium blandowii, Straminergon stramineum or in pure mats; Sp, S-.

*Brachythecium albicans - M: Dryopteris expansa meadows, herb mossy meadows, willow thickets with solitary groups of Anthriscus sylvestris and Dryopteris expansa disturbed by the common eider, on soil and on willow shoots. Grows solitary or with Sciuro-hypnum reflexum, Polytrichastrum alpinum; Un, S-. - B: cloudberry-crowberry communities with peat outcrops frequently visited by gulls; community of Anthriscus sylvestris $(70 \%)$ and Valeriana sambucifolia $(10 \%)$ with an uncovered soil site, in pure mats; $\mathrm{Sp}, \mathrm{S}-$.

B. mildeanum - M, B: inner part of the islands, hygrophyte plant communities with Caltha palustris, willow thickets with sedges, herbs-sphagnum swamps, wellspring. The species usually grows on soil and rarely on doty wood. $\mathrm{Sp}, \mathrm{G}+$.

*B. rivulare - B: three locations: 1) $69^{\circ} 50^{\prime} 9^{\prime \prime} \mathrm{N}-31^{\circ} 34^{\prime} 33^{\prime \prime E}$, $7 \mathrm{~m}$ alt., swampy shore on the southern part of Bolshoe Lake, vegetation site below places frequently visited by birds and therefore covered with guano; on soil with Rhizomnium pseudopunctatum and Plagiomnium ellipticum; 2) 69 50'9"N $-31^{\circ} 33^{\prime} 48^{\prime \prime} \mathrm{E}$, southwestern part of the island, ca. $8 \mathrm{~m}$ alt., wellspring with wooden framework, on soil and in shallow water; 3) $69^{\circ} 50^{\prime} 35^{\prime \prime} \mathrm{N}-31^{\circ} 34^{\prime} 32^{\prime \prime} \mathrm{E}$, ca. $12 \mathrm{~m}$ alt., vicinities of Severnoye Lake, a peat hummock with Tripleurospermum sp., Caltha palustris, and Anthriscus sylvestris used by gull for nesting, in pure mats; Un, G+.

*B. salebrosum - M: coastal and inner parts of the island, Dryopteris expansa meadows, meadows of Angelica archangelica and Anthriscus sylvestris with Caltha palustris; Fr. - B: inner part of the island, Dryopteris expansa and Anthriscus sylvestris meadows and wet willow stand with Caltha palustris, hummocky sedge-dwarf shrub swamps covered with guano, hummocky grasslands with Leymus arenarius and Anthriscus sylvestris, crowberry-cloudberry communities, humaninfluenced grasslands near the lighthouse. Grows on soil in pure mats or in mix with other species; Fr, S-.

Bryum spp. - M, B: coastal and inner rocks, coastal meadows, sites with fine soil, human buildings and ruins, plant communities with sparse cover; Fr.

B. pallescens (B. cirratum) — B: coastal rocks (Häyren, 1955).

*B. pseudotriquetrum - M: rocky S-faced ridge in the southern part of the island, wet rocky crevices and Dryopteris expansa and Anthriscus sylvestris meadows with Rubus chamaemorus; - B: various parts of the island, wet rocks, Dryopteris expan$s a$ and Rubus chamaemorus meadows, willow stands with sedges, Caltha palustris communities with sedges, cracks in cement foundation of the ligththouse, on inundated soil and fine ground, with Calliergon giganteum, Plagiomnium elatum, Helodium blandowii, etc.; Sp, S-.

*Bucklandiella sudetica - B: 69 $50^{\circ} 12^{\prime \prime} \mathrm{N}-31^{\circ} 33^{\prime} 22^{\prime \prime} \mathrm{E}$, ca. $18 \mathrm{~m}$ alt., southwestern part of the island near the triangulation station, at the bottom of a military trench with vertical wall overgrown with Rumex acetosa s.1., Rubus chamaemorus, Rhytidiadelphus squarrosus; in pure mat in a crevice of solitary boulder with epilithic mosses; Un, S-.

Calliergon cordifolium - M: $69^{\circ} 49^{\prime} \mathrm{N}-31^{\circ} 38^{\prime} \mathrm{E}$, ca. $18 \mathrm{~m}$ alt., lake shore, moist site with Caltha palustris group, on wet soil and partly in water. - B: coastal and inner part of island, herbs- and sedges-sphagnum swamps, Comarum palustre carr with massive quantities of guano, moist communities with Caltha palustris, coastal grasslands with Rhodiola rosea, Stellaria crassifolia, willow thickets with Rhizomnium pseudopunctatum and Plagiomnium spp.; on moist soil, in pure mats or with other species; Fr, S-.

C. giganteum - B: vicinities of Bolshoye, Maloye, Sevenoye and Nedostupnost Lakes, Kluchevaya Bay, shores of lakes, herb-mosses swamps, sedge-willow thickets with Plagiomnium spp.; on moist soil and shallow water, in pure mats or with other species; Fr, S-.

*Ceratodon purpureus - M: middle part of the island, meadow of Anthriscus sylvestris, Dryopteris expansa, and Rubus chamaemorus, on soil, with Brachythecium sp.; Rr, S+. - B: crevices of coastal rocks, wooden frame of wellspring, in pure tufts or with different species; Sp, S+. One specimen was extraordinarily coloured in black and dark-red. (KPABG 20461). 
*Dicranum elongatum - M: 6949'12"N - 31³7'57"E, 16 m alt., rocky ridge in southern part of the island, flagging rocks 3-4 m high, plant groups with Prasiola crispa on vertical rock walls; in rock crevices; - B: southwestern part of the island near the triangulation station, at the bottom of a military trench with vertical wall overgrown with Rumex acetosa s.l., Rubus chamaemorus, Rhytidiadelphus squarrosus; shell craters and trenches in the vicinity of the lighthouse; on peat outcrops and in crevices of boulders at the trench bottom, in pure tufts or with different species; Rr, S-.

D. majus - B: peat hummock with crowberry communities among bogs; sedge-sphagnum swamps with groups of Empetrum hermaphroditum, Dryopteris expansa, Rubus chamaemorus and Anthriscus sylvestris; dwarf shrubs (Empetrum sp., Vaccinium myrtillus, V. uliginosum) communities on slopes; moist willow stands; Empetrum sp. - Dryopteris expansa communities; short grass meadows frequently used by gulls for resting among cloudberry-crowberry communities; sedgegrass mossy swamps; shell craters overgrown with Sphagnum sp.; on peat and moist soil, in pure tufts or with Polytrichum strictum, Pleurozium schreberi, Plagiomnium spp., Rhizomnium sp., Rhytidiadelphus squarrosus, Sanionia uncinata, Sciuro-hupnum sp.; Sp, S-.

D. scoparium - M: meadows with Dryopteris expansa, Rubus chamaemorus, Anthriscus sylvestris, and Bryum sp.; crowberry communities with Rubus chamaemorus, Dryopteris expansa; with Sciuro-hypnum reflexum; $\mathrm{Rr}, \mathrm{S}-$. - - B: dwarf shrub communities; human-influenced short grass meadow near the lighthouse; eutrophic birds-influenced swamps of Anthriscus sylvestris, Dryopteris expansa, Caltha palustris, Trientalis europea with massive quantities of guano; peat hummocks in sedge willow communities with Plagiomnium spp.; shell craters overgrown with lichens and ferns; sedge moss swamps; on sandy soil and peat, in pure tufts or with Sanionia uncinata, Plagiomnium elatum, Aulacomnium palustre; Rr, S-. In $1950^{\text {th }} D$. scoparium was common in widespread cloudberrycrowberry communities (Parfentyeva \& Breslina 1969; KAND) and probably these populations are extinct now because of the severe organic enrichment caused by birds.

*Drepanocladus aduncus - B: coastal rocks with puddles and groups of Rhodiola rosea, wet bird-influenced meadows among rock outcrops, sedge-moss swamps, the path from the hut to the well; on moist soil and rocks, in pure mats or with different species; $\mathrm{Sp}, \mathrm{S}$ -

* _ var. polycarpus - B: frame timber at the base of the well, as an addition to Brachythecium mildeanum mats; Un, S-.

*D. polygamus - B: eutrophic swampy puddles with Caltha palustris, Carex aquatilis, C. rariflora; soggy soil, in pure mats or in tufts of other species; Un, S-.

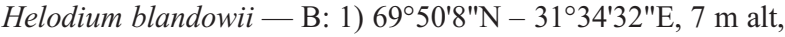
southern shore of Bolshoye Lake, swampy willow sedge thicket, on wet soil, with Calliergon cordifolium, Plagiomnium ellipticum and different hygrophilous mosses. 2) $69^{\circ} 50^{\prime} 24 " \mathrm{~N}$ $-31^{\circ} 34^{\prime} 20$ "E, $7 \mathrm{~m}$ alt, between Severnoye and Nedostupnost Lakes, eutrophic bird-influenced swamp with sedge tussocks about $50 \mathrm{~cm}$ high overgrown with Anthriscus sylvestris, Caltha palustris, Dryopteris expansa, etc.; with Sciuro-hypnum reflexum, Tayloria tenuis, Pohlia sp.; Un, S-. In $1950^{\text {th }}$ Helodium blandowii was recorded from more localities on Bolshoj Ainov Island: in sedge-moss swamps in vicinities of Maloye Lake, on the southwestern shore of Bolshoye Lake, between Bolshoye Lake and the lighthouse and in contact zone between coastal meadow and swampy willow sedge community between Bolshoye Lake and seashore (KAND).

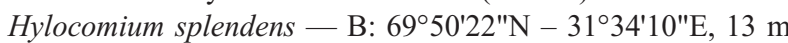
alt., between Nedostupnost Lake and the lighthouse, hummock with Vaccinium myrtillus and Rubus chamaemorus among fern meadow; on soil, with Sciuro-hypnum reflexum, Sanionia uncinata; Un, S-. In $1950^{\text {th }}$ N.S. Parfentyeva \& I.P. Breslina (1969) pointed out that Hylocomium splendens occurred frequently in willow sedge swamps in small quantities. The specimens were collected in vicinities of Bolshoye, Maloye and Sredneye Lakes, Mochevaya and Kluchevay Bays. *Leptobryum pyriforme - M: 6949'12"N - 31 ${ }^{\circ} 37^{\prime} 57^{\prime \prime} \mathrm{E}, 16 \mathrm{~m}$ alt., rocky ridge in southern part of the island, flagging rocks 3-4 m high, plant groups with Prasiola crispa on vertical rock walls, with Bryum sp. Un, S+. - B: various parts of the island, human-influenced habitats: crumbling sandstone rocks, meadows with peat hummocks often visited by gulls, timber in the base of the well; on soil and fine soil, wet doty wood, usually in mixed tufts; $\mathrm{Rr}, \mathrm{S}+$.

*Loeskypnum badium - M: 6949'12"N - 31³7'57"E, 16 m alt., S-faced slope in southern part of the island, platy crumbled rocks 3-4 m high with plant groups of Rubus chamaemorus, Bryum sp. and algae Prasiola crispa on the cliffy sites, soggy moss cover on the vertical wall; Un, $\mathrm{S}-$. - - B: $69^{\circ} 50^{\prime} 16^{\prime \prime} \mathrm{N}$ $-31^{\circ} 33^{\prime} 10^{\prime \prime E}, 3 \mathrm{~m}$ alt., western coast of the island, bird-influenced moist grass-starwort-moss meadow among coastal rocks; on soggy soil and wet rocks; $69^{\circ} 50^{\prime} 25^{\prime \prime} \mathrm{N}-31^{\circ} 33^{\prime} 24^{\prime \prime} \mathrm{E}, 5 \mathrm{~m}$ alt., western coast of the island, terraced coastal W-faced rock outcrops with meadows of Rhodiola rosea, Rubus chamaemosus, Chamaepericlymenum suecicum; Un, S-. Specimens of Loeskypnum badium have unexpected green coloration.

* Mnium hornum - B: coastal and inner part of the island, coastal meadows among rock outcrops, moist plant communities with Caltha palustris, margins of willow thickets with Dryopteris expansa-Rubus chamaemorus community among vast fern meadows, on soil. Pure tufts or with different mosses; Rr, S-

Paludella squarrosa - B: In $1920^{\text {th }}$ finish botanists E. Häyrén and $\mathrm{K}$. Linkola collected two specimens of $P$. squarrosa (H4103270, H4103277). Three decades later N.S. Parfentyeva observed more localities of the species on the island: in sedgemoss swamps in vicinities of Maloye and Bolshoye Lakes, on the southwestern shore of Bolshoye Lake, sedge-cotton grass swamp on a shore of Nedostupnost Lake, swampy willow sedge community between Bolshoye Lake and seashore (KAND); P. squarrosa commonly grows with Plagiomnium elatum, $\mathrm{He}$ lodium blandowii, Aulacomnium palustre, Sphagnum sp. However, in $21^{\text {st }}$ century the species was not found on the Ainov Islands.

*Plagiomnium elatum - In $1950^{\text {th }}$ the species was collected in different parts of Bolshoi Ainov Island: sedge-moss swamps with willow sites in vicinities of Bolshoye and Maloye Lakes, willow thickets on the southern shore of Nedostupnost Lake, crowberry cloudberry community between Bolshoye and Sredneye Lakes, willow swamp near the coastal line. Plagiomnium elatum grew with Paludella squarrosa, Helodium blandowii, Bryum pseudotriquetrum Dicranum scoparium, Aulacomnium palustre, and Sciuro-hypnum sp. We failed to find the species in 2010.

*P. medium - B: 1) $69^{\circ} 50^{\prime} 8 " \mathrm{~N}-31^{\circ} 33^{\prime} 51^{\prime \prime} \mathrm{E}, 6 \mathrm{~m}$ alt., the path from the hut to the well, moist meadow with Filipendula ulmaria, Geum rivale, Anthriscus sylvestris, Urtica dioica s.1.; 2) $69^{\circ} 50^{\prime} 22^{\prime \prime} \mathrm{N}-31^{\circ} 34^{\prime} 25^{\prime \prime} \mathrm{E}, 9 \mathrm{~m}$ alt., central part of the is- 
land, northern shore of Nedostupnost Lake, swamp with Comarum palustre; in pure mats on soil; Un, $\mathrm{S}-$.

P. ellipticum - M, B: predominantly in various habitats in the inner parts of the islands: moist meadows with Rhodiola rosea and grasses, various swamps, sedge tussocks communities, Dryopteris expansa and Rubus chamaemorus meadows, willow stands and coastal meadows. It is one of the most common species, growing in pure mats or with different hygrophyte and mesophyte mosses; Com, $\mathrm{G}+, \mathrm{S}+$.

*Plagiothecium cavifolium - M: $69^{\circ} 49^{\prime} \mathrm{N}-31^{\circ} 38^{\prime} \mathrm{E}, 16 \mathrm{~m}$ alt, eastern shore of a lake in the central part of the island, moist depression among a fern meadow, on soil; Un, S-.

*P. denticulatum - M, B: Dryopteris expansa and Rubus chamaemorus meadows, tussock communities of Leymus arenarius, crowberry thickets, willow stands, high sites in herb and sedge-sphagnum swamps, peaty hummocks used by gulls for nesting and rest; on soil, seldom on willow stems and in crevices of boulders. Sometimes the species was collected in bird-influenced sites with massive amounts of guano, in pure mats or in mixed moss cover; $\mathrm{Fr}, \mathrm{S}+$.

*P. laetum - B: $69^{\circ} 50^{\prime} 34^{\prime \prime} \mathrm{N}-31^{\circ} 34^{\prime} 8^{\prime \prime} \mathrm{E}, 14 \mathrm{~m}$ alt, central part of the island, $300 \mathrm{~m}$ southern from Severnoye Lake, on the wooden roof of blindage overgrown with vascular plants and mosses, vertical wall with peaty soil, in pure mats; Un, S-.

*P. latebricola - M: $69^{\circ} 49^{\prime} 12^{\prime \prime} \mathrm{N}-31^{\circ} 37^{\prime} 57^{\prime \prime E}, 16$ m alt., Sfaced slope in southern part of the island, platy crumbled rocks 3-4 m high with plant groups of Rubus chamaemorus, Bryum sp. and algae Prasiola crispa on the cliffy sites, soggy moss cover on the vertical wall; fissures of vertical rocky wall and semidry rock in moist grot with stream; - B: 1) $69^{\circ} 50^{\prime} 15^{\prime \prime} \mathrm{N}$ $-31^{\circ} 33^{\prime} 9$ 'E, $4 \mathrm{~m}$ alt., southwestern shore of the island, birdinfluenced meadow of grasses and Sanionia sp. with massive quantities of guano among terraced S-faced rocks covered by nitrophilous algae Prasiola crispa, in pure mats on peaty soil; 2) $69^{\circ} 50^{\prime} 16^{\prime \prime} \mathrm{N}-31^{\circ} 33^{\prime} 10^{\prime \prime} \mathrm{E}, 3 \mathrm{~m}$ alt., western part of the island, above coast communities, rocky outcrops covered with Rubus chamaemorus among thickets of Anthriscus sylvestris, at the shield base of rocks on the vertical wall, solitary; 3) $69^{\circ} 50^{\prime} 25^{\prime \prime} \mathrm{N}-31^{\circ} 33^{\prime} 24^{\prime \prime} \mathrm{E}, 5 \mathrm{~m}$ alt., western coast of the island, terraced coastal western exposure rocks divided by horizontal sites with meadow of Rhodiola rosea, Rubus chamaemorus, and Chamaepericlymenum suecicum, a scarp between rocky ridges; $\mathrm{Un}, \mathrm{G}+$, $\mathrm{S}-$.

Pleurozium schreberi - several specimens were collected by N.S. Parfentyeva (KAND) in $1950^{\text {th }}$ : M: southern part of the island, small depressions on the slope, solitary; — B: between Sredneye and Maloye Lakes, forb site among willow thickets, rare, in mixed cover with Hylocomium splendens, Sanionia uncinata, Rhytidiadelphus squarrosus, Dicranum majus, Rhizomnium sp., Sciuro-hypnum sp. We did not find the species in 2010 .

*Pohlia cruda - B: 6950'25"N - 31³3'24"E, 5 m alt., western shore of the island, coastal W-faced terraced rocks with short grass meadow of Rhodiola rosea, Rubus chamaemorus, Chamaepericlymenum suecicum, solitary; Un, S-.

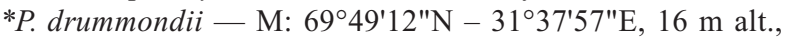
$\mathrm{S}$-faced slope in southern part of the island, platy crumbled rocks 3-4 m high with plant groups of Rubus chamaemorus, Bryum sp. and algae Prasiola crispa on the cliffy sites, in fissures of crumbling rocks; Un, $\mathrm{P}+$.

*P. nutans - M, B: fern meadows, peaty hummocks, tussocks of Leymus arenarius, rocky outcrops, crowberry and crow- berry-cloudberry communities, various swamps, human-influenced habitats; in pure tufts or with different mosses; Com, $\mathrm{S}+$. *Polytrichastrum alpinum — M: 1) 69॰49'16"N - 31 $39^{\circ} 8^{\prime} 6 " \mathrm{E}$, $16 \mathrm{~m}$ alt., middle part of the island, a depression with willow stands and separate sites of Anthriscus sylvestris and Dryopteris expansa transformed by nesting activity of the common eider; with Sciuro-hypnum reflexum, Brachythecium albicans; 2) shore of Nedostupnost Lake, willow stand; Un, S-.

Polytrichum commune - B: one location in $300 \mathrm{~m}$ east-northeast from the hut, on a microhill between tussocks of a sedge swamp with Dryopteris expansa, Caltha palustris, Anthriscus sylvestris; on soil, in mixed tufts with Sphagnum russowii; Un, S-.

*P. juniperinum - M: cloudberry-sphagnum meadow, on peaty hummocks with mosses; - B: peaty hummocks among meadows or swamps, rest and nesting sites of gulls, human-influenced places; on soil, mixed or in pure tufts; Sp, S-.

*P. longisetum - M, B: inner parts of the islands, peaty hummocks, cloudberry communities, sites influenced by military activity; on soil, in pure tufts or with different species; $\mathrm{Sp}$, $\mathrm{S}+$.

* _ var. anomalum - M, B: middle parts of the islands, crowberry and crowberry-cloudberry communities, fern meadows, peaty hummocks among meadows or swamps, rest and nesting sites of gulls; on soil, in mixed tufts with different species; Sp, S-.

P. strictum - B: peaty hummocks and rest places of gulls, among fern meadows and cloudberry-crowberry communities, humaninfluenced places; on soil, in pure tufts; $\mathrm{Rr}, \mathrm{S}-$.

*Rhizomnium magnifolium - B: willow thickets, sedge-sphagnum swamps; on soil, in pure mats or with Sphagnum fimbriatum, Straminergon stramineum; Rr, S-.

*R. pseudopunctatum - B: herb-sphagnum swamps, fringe of wet willow thickets, vegetation site below places frequently visited by birds, therefore covered with massive amounts of guano; on soggy soil, with Plagiomnium sp. and Straminergon stramineum; $\mathrm{Rr}, \mathrm{S}+$.

Rhytidiadelphus squarrosus - B: inner part of the island, peaty hummocks with cloudberry and crowberry, rest sites of gulls, military trenches, meadow with Geranium sylvaticum and Viola biflora; on soil in mixed tufts; Sp, S-. In $1950^{\text {th }}$ Parfentyeva \& Breslina (1969) pointed out that Rhytidiadelphus squarrosus occurred on coastal meadows, but in 2010 the species was recorded from the inner part of the island only.

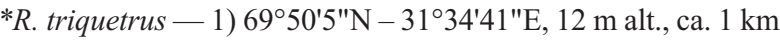
east-south-east from the lighthouse, wide peaty hummocks with cloudberry moss communities, with forbs inhabited by gulls; lateral surface of a peat hummock with Rhytidiadelphus squarrosus and Sanionia orthothecioides; 2) 69 50'22"N $-31^{\circ} 34^{\prime} 10^{\prime \prime E}, 13 \mathrm{~m}$ alt., central part of the island, between Nedostupnost Lake and the lighthouse, peat hummock with blueberry and cloudberry among a vast fern meadow; on soil in pure tufts; Un, S-.

* Sanionia orthothecioides - M, B: coastal and inner parts of the islands, moist shore grass-moss meadows, peaty hummocks with cloudberry and crowberry, rest sites of gulls, community of Chamaenerion angustifolium and Leymus arenarius on a lake shore; in pure or mixed tufts; Sp, G+.

S. uncinata - M, B: mostly inner and, rarely, coastal parts of the islands, peaty hummocks and rest sites of gulls, dry sites 
among swamps, coastal meadows; on soil, usually in mixed tufts; Fr, S+

*Schistidium maritimum — B: 6950'39" N - 31³3'41" E, 4 m alt., western coast of the island, NE-faced rock outcrops about $1 \mathrm{~m}$ high beside an Anthriscus sylvestris community, in fissures of a platy crumbled rock wall; Un, S+.

*Sciuro-hypnum latifolium - B: 1) 6950'2"N - 31³3'59"E, 4-5 m alt., $300 \mathrm{~m}$ east from the hut, meadow of Geranium sylvaticum and Viola biflora with Rhytidiadelphus squarrosus, on soil between grass shoots; 2) 69 $50^{\circ} 24^{\prime \prime} \mathrm{N}-31^{\circ} 34^{\prime} 20^{\prime \prime} \mathrm{E}$, $7 \mathrm{~m}$ alt., southeast from Severnoye to Nedodtupnost Lakes, swamp with sedge tussocks about $0.5 \mathrm{~m}$ high covered with Dryopteris expansa, Caltha palustris, Anthriscus sylvestris, and Trientalis europaea with massive amounts of guano; on dead grasses in depression between tussocks; 3) $69^{\circ} 49^{\prime} 48^{\prime \prime} \mathrm{N}$ $-31^{\circ} 35^{\prime} 21$ "E, $10 \mathrm{~m}$ alt., eastern coast of the island, $800 \mathrm{~m}$ north from Robinsonov Cape, dense willow stand fringed by Caltha palustris, Anthriscus sylvestris, and Angelica archangelica; on soil; Un, S+.

*S. curtum - M, B: coastal meadows with Rhodiola rosea, communities of Dryopteris expansa, Caltha palustris, Anthriscus sylvestris, and Angelica archangelica, willow thickets; on soil and dead grasses; $\mathrm{Rr}, \mathrm{S}-$.

$* S$. reflexum - M, B: in various plant communities: Dryopteris expansa, Rubus chamaemorus, Geranium sylvaticum, Viola biflora meadows, crowberry tundra with thickets of Rubus chamaemorus and Anthriscus sylvestris, crowberry-foxberry communities with Dryopteris expansa, willow thickets with Dryopteris expansa and Anthriscus sylvestris, moist sites with Caltha palustris, peaty hummocks covered with cloudberry, forbs and Plagiomnium sp., sedge-sphagnum swamps, birdinfluenced sedge tussock swamps, separate stones; various substrates: peat, soil, stones, willow shoots and dead wood. It is one of the most common species. Com, S+.

*S. starkei - M, B: willow stands, fern and forbs meadows, sites with Leymus arenarius tussocks and Anthriscus sylvestris, segde-sphagnum swamps, peaty hummocks used by gulls for resting, cement foundation of the lighthouse; on soil, rarely on stones, in pure mats or with different species; Fr, S-.

Sphagnum angustifolium - B: east shore of Zapadnoye Lake, sphagnous swamp with sedges on a margin and hollow in the centre; in pure mats; Un, S-.

${ }^{*} S$. fimbriatum - B: 1) $69^{\circ} 50^{\prime} 15^{\prime \prime} \mathrm{N}-31^{\circ} 33^{\prime} 48^{\prime \prime} \mathrm{E}, 9 \mathrm{~m}$ alt., near the path between the lighthouse and the hut, small sedgesphagnum swamp, in pure cover or with Straminergon stramineum, Rhizomnium magnifolium; on soggy soil; 2) $69^{\circ} 50^{\prime} 34^{\prime \prime} \mathrm{N}-31^{\circ} 34^{\prime} 8^{\prime \prime} \mathrm{E}, 14 \mathrm{~m}$ alt, $300 \mathrm{~m}$ south from Severnoye Lake, fringe of small sedge-sphagnum swamp; Un, S.

*S. lindbergii - B: inner parts of the island, sedge-tussocks swamps, soggy sedge-sphagnum swamps; in pure cover; Rr, $\mathrm{S}-$.

S. riparium - B: frequent in inner parts of the island (vicinities of Severnoye, Zapadnoye and Bolshoye Lakes) and rare near the sea shore; in wet sedge-sphagnum and sphagnum swamps; in pure cover or with different species; $\mathrm{Sp}, \mathrm{S}-$.

*S. russowii - B: one location in $300 \mathrm{~m}$ east-north-east from the hut, in a depression among tussocks of sedge swamp with Dryopteris expansa, Caltha palustris, Anthriscus sylvestris; in pure cover or with Polytrichum commune on soggy peat; Un, S.

S. squarrosum - B: wet sedge-sphagnum and cotton grasssphagnum swamps, swampy shores of lakes, Comarum palustre mossy flooded swamps, wet meadows, willow thickets; on soggy soil and in water; Fr, S-
S. teres - B: cotton grass and sedge-moss swamps; Rr, S-.

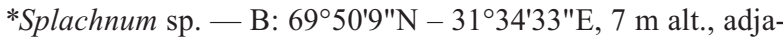
cent to southern shore of Bolshoye Lake, eutrophic Comarum palustre swamp with massive quantities of guano. The species forms a pure tuft about $1 \mathrm{~m}$ in diameter on soggy soil; Un, G+, S-

*Splachnum vasculosum - B: 6950'22"N - 31³4'25"E, 9 m alt., on the shore of Nedostupnost Lake, in Comarum palustre moss swamp; among hummocks on soggy soil, in pure tuft; Un, S-.

Straminergon stramineum - B: in the inner part of the island, sedge-sphagnum and grass-sphagnum swamps, peaty hummocks used by gulls for resting, on soggy soil. Grows usually with Aulacomnium palustre, Sphagnum sp., Rhizomnium pseudopunctatum; $\mathrm{Sp}, \mathrm{S}-$.

*Tayloria tenuis - B: 69॰50'24"N - 31 ${ }^{\circ} 34^{\prime} 20 " \mathrm{E}, 7$ m alt., between Severnoye and Nedostupnost Lakes, eutrophic birdinfluenced swamp with sedge tussocks about $50 \mathrm{~cm}$ high overgrown with Anthriscus sylvestris, Caltha palustris, Dryopteris expansa, etc; with Sciuro-hypnum reflexum, Helodium blandowii, Pohlia sp.; Un, S+.

*Tetraphis pellucida - M: 6949'12"N - 31³7’57"E, 16 m alt., S-faced slope in southern part of the island, platy crumbled rocks 3-4 $\mathrm{m}$ high with plant groups and algae Prasiola crispa on cliffy sites, soggy moss cover on the vertical wall; Un, P+, S-. — B: 69 50 '34"N - 31 ${ }^{\circ} 34^{\prime} 8 " \mathrm{E}, 14 \mathrm{~m}$ alt, $300 \mathrm{~m}$ from Severnoye Lake, trench about 1.5-2 $\mathrm{m}$ deep with vertical walls and wooden constructions, on peaty soil on the walls, in pure mats and with Pohlia nutans; Un, $\mathrm{P}+, \mathrm{S}-$.

*Warnstorfia exannulata - B: grass-sphagnum and marshy cinquefoil-moss swamps; on soggy soil and at the base of tussocks, in pure mats or with different mosses; $\mathrm{Rr}, \mathrm{S}-$.

*W. fluitans - M: 6949'12"N - 31³7'57"E, 16 m alt., S-faced slope in southern part of the island, platy crumbled rocks 3$4 \mathrm{~m}$ high with moss and vascular plant groups and algae Prasiola crispa on cliffy sites; soggy moss cover on the vertical wall; Un, $\mathrm{S}-$. - - B: various parts of the island, coastal rocks and mossy short grass meadows covered with guano, bank of the brook, sedge-sphagnum swamps, meadows with Anthriscus sylvestris and tussocks of Leymus arenarius; on soggy soil, fine ground in moist rock crevices, in pure mats or with different mosses; $\mathrm{Rr}, \mathrm{G}+$, S+.

\section{EXCLUDED TAXA}

Five species from the collection of N.S. Parfentyeva (KAND) were reidentified as follow: Aulacomnium turgidum $>$ A. palustre; Plagiothecium piliferum $>$ Brachythecium salebrosum; Sphagnum majus $[S$. dusenii $]>S$. riparium; Sphagnum subsecundum $>S$. teres. The records of Sphagnum capillifolium [S. nemoreum] (Parfentyeva \& Breslina, 1969) and Sphagnum balticum (Parfentyeva, 1969) are ambiguous; specimens were not found in KAND, KPABG and MW.

\section{DISCUSSION}

Bryoflora of the Ainov Islands is generally regarded as poor in species. In total, 66 species with 3 infraspecific taxa were found there; it is the lowest number of species known from island floras of the European Subarctic (Table 1). Various reasons may be considered for the low bryophyte diversity of this archipelago. First and foremost, the Islands area is extremely small; consequently, the habitat 
Table 1. Number of species in the island floras of the European Subarctic (*-preliminary data)

\begin{tabular}{|c|c|c|c|}
\hline \multirow[t]{2}{*}{ Name of islands } & $\begin{array}{l}\text { Number } \\
\text { of species }\end{array}$ & Area, ha & Literature sources \\
\hline & \multicolumn{3}{|c|}{ Varanger Fjord Bay of the Barents Sea } \\
\hline \multirow[t]{2}{*}{ Ainov Islands } & 66 & 266 & Authors' data \\
\hline & \multicolumn{3}{|c|}{ Onega Bay of the White Sea } \\
\hline Solovetsky Islands & $84 *$ & 34700 & Maksimov \& Maksimova, 2002 \\
\hline \multirow[t]{2}{*}{ Kuzova Islands } & $93 *$ & $\sim 890$ & Maksimov \& Maksimova, 2002 \\
\hline & \multicolumn{3}{|c|}{ Kandalaksha Bay of the White Sea } \\
\hline Oleniy Island & 155 & 1002 & Belkina \& Likhachev, 1997 \\
\hline Velikiy Island & 162 & 7148 & Belkina \& Likhachev, 1997 \\
\hline Ryazhkov Island & 138 & 465 & Belkina \& Likhachev, 1997 \\
\hline Kem-Ludy Islands & 151 & $\sim 451$ & Belkina \& Likhachev, 1997 \\
\hline Porya Guba Archipelago & 170 & 535 & Kozhin, 2015 \\
\hline
\end{tabular}

diversity is limited. Vegetation comprises a low variety of plant communities dominated by one or several species. Second, vast bird rookeries have been providing an obvious negative impact on ecosystem diversity for decades. Third, northward location and harsh marine conditions, namely strong winds and severe impulverization, are also considered as a limiting factors.

Only two records can be described as especially peculiar. Of particular interest was the record of Plagiothecium latebricola on the both Ainov Islands as it is known from coastal ornithogenous meadows on mouldering soil on Bolshoi Gavrilovskiy Island of the Murman Coast of the Barents Sea. This species is widespread in boreal zone of Russia on decayed wood; however, earlier it had not been reported from the Russian Arctic. Another interesting finding is Mnium hornum; this species sporadically occurs in Murmansk Province on the northeastern range limit (Konstantinova et al., 2014).

The contemporary moss component of the Island plant cover is apparently incomplete. The impoverishment of the flora is mostly generated by various aspects of longterm bird influence. Although a characteristic feature of the tundra-like vegetation is low number of species, especially of mosses, on these islands most common moss species of zonal hypoarctic vegetation are absent or grow in scarce populations. Small amounts of Hylocomium splendens, Dicranum scoparium and D. majus sporadically occur in the communities meanwhile Dicranum elongatum was found only in unfavourable disturbed habitats. Noteworthy, Pleurozium schreberi was not observed in 2010 and therefore could be claimed extinct. However, the species listed above are widespread on the neighbouring territories of the Sredniy and the Rybachy Peninsulas.

The moss diversity of swamps is predominantly represented by species resistant to eutrophic conditions, e.g., Aulacomnium palustre, Calliergon cordifolium, C. giganteum, Loeskypnum badium, Plagionmium ellipticum, Sphagnum riparium, and $S$. squarrosum. Less resistant species are almost absent due to the bird impact.

Another characteristic feature of the Island flora is almost entire absence of epilithic mosses. Bryum spp. are single representatives of epiliths on the coastal rocks, while not only Bryum spp., but also Pohlia nutans, P. cruda and $P$. drummondii sporadically occur on rocks in the inner parts of the Islands. However, the only unique record of a typical epilith Bucklandiella sudetica was detected on the solitary stone in the old trench (Fig. 9). The stone is situated in a slight depression among tall buckler ferns and consequently is not exposed to destructive influence of gulls.

As previously mentioned, both population level and species composition of sea birds experienced drastic changes during the $20^{\text {th }}$ century. As vast rookeries of Atlantic puffins commonly occupied island slopes, summit plains were not transformed by their activity. According to literature (Parfentyeva, 1969; Parfentyeva \& Breslina, 1969) the most common moss species of tundra-like vegetation, as well as typical swamp species were more abundant and constant in the middle of the $20^{\text {th }}$ century. Later the population level of the sea gulls rapidly increased and therefore caused organic enrichment of the Island ecosystems leading to extinction of several species. Pleurozium schreberi disappeared from the tundra-like communities as well as Paludella squarrosa, Plagiomnium elatum - from the swamps. The decline in occurrence was observed in populations of Dicranum scoparium, Hylocomium splendens, Helodium blandowii and Rhytidiadelphus squarrosus.

On the contrary, Sanionia uncinata, Aulacomnium palustre, Calliergon stramineum and Sphagnum squarrosum were able to survive in these harsh conditions due to their eutrophication resistance. The same effect was reported from ornithogenic communities of Svalbard (Klekowski \& Opalinski, 1986; Koroleva, 2004).

Furthermore, only few species of Splachnaceae were found on the Islands; however, they have frequent occurrence on the neighbouring territories, as well as on the Kola Peninsula (Schljakov \& Konstantinova, 1982). These species prefer to grow on fertilized organic substrates and consequently indicate a process of ecosystem organic enrichment. In particular, Splachnum vasculosum was registered as a component of ornithogenic tundra of Svalbard (Klekowski \& Opalinski, 1986) as well as on the Bolshoi Ainov Island. 
Additional evidence of the high trophic level of the Ainov Islands' ecosystems is a high occurrence of nitrophilous alga Prasiola crispa and cyanobacteria Phormidium spp. (Davydov et al., 2012). These species are particularly widespread in ornithogenic ecosystems from Antarctic to Arctic due to their outstanding ability to tolerate extremely high nutrient concentrations and high disturbance level of bird activity. These taxa are well-known to be associated with bird nesting sites (Smykla et al., 2007).

The problem of organic enrichment of the island ecosystems is widely acknowledged. Special research of this process was conducted on numerous islands and archipelagos (e.g., Hogg \& Morton, 1983; Breslina, 1987; Vidal et al., 1998; Wait et al., 2005). However, very few investigations were devoted to bird influence on bryophytes (Melick, 1994; Smykla et al., 2007). This study provided a detailed description of various succession stages on the Subantarctic island ecosystems caused by penguin impacts. In particular, mosses were predominantly observed in zones with low penguin impact or lack of it, while algae and vascular plants were detected throughout the rookeries. The ecological gradient pattern of moss distribution is regarded as analogous to that of Subarctic island ecosystems. In the $20^{\text {th }}$ century, an overwhelming gull influence on the Ainov Islands is evident as a decrease in moss diversity along with significant changes in vegetation, especially moss occurrence, were observed.

Remarkably, after more than three decades the trophic level of terrestrial ecosystems on the Ainov Islands remains high in spite of gull population decrease and water runoff.

\section{ACKNOWLEDGEMENTS}

Authors are sincerely grateful to A. Ivanova and T. Gavrilova for improving English. The work of Kozhin was partially supported by RFBR grants 16-05-00644, 15-29-02662, 14-04-01424, of Belkina by RFBR 15-2902662, and of Ignatova by RBFR project 14-04-01424.

\section{LITERATURE CITED}

[BELKINA, O.A. \& A.YU. LIKHACHEV] БЕЛКИНА О.А., А.Ю. ЛИХАЧЕВ. 1997. Конспект флоры листостебельных мхов Кандалакшского заповедника (Белое море). - [Mosses of the Kandalaksha State Nature Reserve (the White Sea)] Anатиты [Apatity], 48 pp.

[BRESLINA, I.P.] БРЕСЛИНА И.П. 1971. Приморские вороничники особые тундрообразные экстразональные образования. - [Coastal crowberry heaths - specific extrazonal tundra-like communities] Природa и хозяйство Севера [Priroda i khozyaistvo Severa] 3: 89-91

[BRESLINA, I.P.] БРЕСЛИНА И.П. 1987. Растения и водоплавающие птицы морских островов Кольской Субарктики. - [Plants and waterfowl of marine islands of the Kola Subarctic] Л., Наука [Leningrad, Nauka], $200 \mathrm{pp}$.

[DAVYDOV, D.A., A.YU. MELEKHIN \& E.A. BOROVICHEV] ДАВЫДОВ Д.А., А.В. МЕЛЕХИН, Е.А. БОРОВИЧЕВ. 2012. Цианопрокариоты, лишайники и печеночники Айновых островов (Кандалакшский заповедник, Мурманская область). - [Cyanoprokaryota, lichens and liverworts of the Ainov Islands (Kandalaksha reserve, Murmansk Province)] Ученые записки Петрозаводского государственного университета [Uchenye zapiski Petrozavodskogo gosudarstvennogo universiteta] 4: 33-38.

EMEIS, W. 1929. Ein Besuch der Vogelinsel Heinäsaaret an der finnischen Eismeerküste. - Journal für Ornithologie 77(2): 229-242.
[GEORGIEVSKIJ, A.В.] ГЕОРГИЕВСКИЙ А.Б. 1980. На Айновых островах. - [On the Ainov Islands] Природа [Priroda] 12: 53-55.

[GERASIMOVA, T.D.] ГЕРАСИМОВА Т.Д. 1951. Материалы по экологии тупика - Fratercula arctica L. - [Information about ecology of the Atlantic puffin Fratercula arctica L.] Ученые записки Московского городского педагогического института им. В.П.Потемкина [Uchenye zapiski Moskovskogo gorodskogo pedagogicheskogo instituta im. V.P.Potjomkina] 18: 115-124.

[GERASIMOVA, T.D.] ГЕРАСИМОВА Т.Д. 1958. К орнитофауне Айновых островов. - [To avifauna of the Ainov Islands] B кн. Труды Кандалакшского государственного заповедника. Bып. 1 (отв. ред. Дубинин, В.Б.) Вологда, Вологодское книжное издательство [In: Dybinin, V.B. Trudy Kandalakshskogo gosudarstvennogo zapovednika 1. Vologda, Vologodskoe knizhnoe izdatel'stvo]: 37-50.

HOGG, E.H. \& J.K. MORTON. 1983. The effects of nesting gulls on the vegetation and soil of islands in the Great Lakes. - Canadian Journal of Botany 61(12): 3240-3254.

HÄYREN, E. 1955. Mossor fran Lapponia petsamoensis. - Memoranda Societatis pro Fauna et Flora Fennica 31: 56-62.

HÄYREN, E. 1927. Pummanginniemi i Petsamo sesom Naturskyddsomrede. - Silva Fennica 3: 1-21+4

IGNATOV, M.S., O.M. AFONINA, E.A. IGNATOVA, with contributions on regional floras from: A.A. ABOLINA, T.V. AKATOVA, E.Z. BAISHEVA, L.V. BARDUNOV, E.A. BARYAKINA, O.A. BELKINA, A.G. BEZGODOV, M.A. BOYCHUK, V.YA. CHERDANTSEVA, I.V. CHERNYADJEVA, G.YA. DOROSHINA, A.P. DYACHENKO, V.E. FEDOSOV, I.L. GOLDBERG, E.I. IVANOVA, I. JUKONIENE, L. KANNUKENE, S.G. KAZANOVSKY, Z.KH. KHARZINOV, L.E. KURBATOVA, A.I. MAKSIMOV, U.K. MAMATKULOV, V.A. MANAKYAN, O.M. MASLOVSKY, M.G. NAPREENKO, T.N. OTNYUKOVA, L.YA. PARTYKA, O.YU. PISARENKO, N.N. POPOVA, G.F. RYKOVSKY, D.YA. TUBANOVA, G.V. ZHELEZNOVA \& V.I. ZOLOTOV. 2006. Check-list of mosses of East Europe and North Asia. - Arctoa 15: 1-130.

[IVANENKO, N. YU.] ИВАНЕНКО Н.Ю. 2013а. Изменение орнитофауны острова Большой Айнов (Баренцево море, Варангер-фьорд). - [Change of avifauna on the Bolshoi Ainov Island, Varanger Fjord Bay of the Barents Sea] Русский орнитологический журнал [Russskij ornitologicheskij zhurnal] 22(931): 2898-2899.

[IVANENKO, N. YU.] ИВАНЕНКО Н.Ю. 2013b. Особенности гнездования серого гуся на Айновых островах (Варангер-фьорд, Баренцево море). - [Nesting peculiarities of the greylag goose Anser anser on the Ainov Islands, Varanger Fjord Bay of the Barents Sea] Русский орнитологический журнал [Russskij ornitologicheskij zhurnal] 22(855): 649-650.

KALELA, A. 1939. Über Wiesen und Wiesenarctige Pflanzengesellschaften auf der Fischerhalbinsel in Petsamo Lappland. - Acta Forestalia Fennica 48: 1-523.

KLEKOWSKI, R.Z. \& K.W. OPALINSKI. 1986. Matter and energy flow in Spitsbergen ornithogenic tundra. - Polar Research 4(2): 187-197.

[KONSTANTINOVA, N.A., A.S. KORYAKIN, O.A. MAKAROVA, V.V. BIANKI] КОНСТАНТИНОВА, Н.А., А.С. КОРЯКИН, О.А. МАКАРОВА, В.В. БИАНКИ. 2014. Красная Книга Мурманской области [Red Data Book of the Murmansk Province]. - Кемерово, Азия-Принт [Kemerovo, Asia-Print Publishing], 584 pp.

[KOROLEVA, N.E.] КОРОЛЕВА Н.Е. 2004. Состав орнитогенной растительности на южном побережье залива Белльсунн (Западный Шпицберген). - [Ornitogenic vegetation on the south shore of Belsund Bay, western Spitsbergen] В кн.: Комплекснье исследования природы Шпицбергена. Сборник материалов IV международной конференции (08-10 апреля 2004, Мурманск) Апатить: КНЦРАН [In.: Kompleksnye issledovanija prirody Shpicbergena IV. Proceedings of the workshop (08-10 April 2004, Murmansk) Apatity: Kola Sci. Center of RAS]: 255-263.

[KOZHIN, M.N.] КОЖИН М.Н. 2015. История изучения и новые данные о флоре листостебельных мхов беломорской части Кандалакшского заповедника. - [The history of study and new data to moss 
flora of the White Sea part of the Kandalaksha Reserve] Материалы Международной бриологической конферениии, посвященной 100-летию со дня рождения Анастасии Лаврентьевны Абрамовой (12-16 октября 2015, Санкт-Петербург). СПб СПбГЭТУ “ЛЭТИ" [In.: International Bryological conference dedicated to 100 year anniversary of A.L. Abramova (12-16 October 2015, St. Petersburg). Proceedings of the workshop St. Petersburg: SPbGETU 'LETI']: 67-71.

MAKSIMOV, A.I. \& T.A. MAKSIMOVA. 2002. Mosses of the White Sea islands. - In: Shcherback P. (ed.) Natural and cultural heritage of the White Sea. Petrozavodsk, Karelian Research Centre: 97-101.

MELICK, D.R., M.J. HOVENDEN \& R.D. SEPPELT. 1994. Phytogeography of bryophyte and lichen vegetation in the Windmill Islands, Wilkes Land, Continental Antarctica. - Vegetatio 111(1): 71-87.

NOVAKOVSKIY, A.B. \& V.V. ELSAKOV. 2014. Hydrometeorological database (HMDB) for practical research in ecology. - Data Science Journal 13: 57-63.

[PARFENTYEVA, N.S.] ПАРФЕНТЬЕВA Н.C. 1969. Растительность Айновых островов. - [The vegetation of the Ainov Islands] $B \kappa н .:$ Tpydbl Кандалакшского государственного заповедника. Bыn. 7 (ред. Раменская М.Л.). Мурманск, книжное издательство [In: Ramenskaya, M.L. (ed.). Trudy Kandalakshskogo gosudarstvennogo zapovednika. 7. Murmansk, knizhnoe izdatel'stvo]: 413-424.

[PARFENTYEVA, N.S. \& I.P. BRESLINA] ПАРФЕНТЬЕВА Н.С., И.П. БРЕСЛИНА. 1969. Флора Айновых островов - [The flora of the Ainov Islands] В кн.: Труды Кандалакшского государственного заповедника. Вып. 7 (ред. Раменская М.Л.). Мурманск, книжное издательство [In: Ramenskaya, M.L. (ed.). Trudy Kandalakshskogo gosudarstvennogo zapovednika. 7. Murmansk, knizhnoe izdatel'stvo]: 390-412.

PEARSON, H.J. 1904. Three summers among the birds of Russian Lapland. - London, R.H. Porter, $x v i+216+68+1 p p$.

[SAFRONOVA, I.N., T.K. YURKOVSKAYA, I.M. MIKLYAEVA \& G.N. OGUREEVA] САФРОНОВА И.Н., Т.К. ЮРКОВСКАЯ, И.М. МИКЛЯЕВА, Г.Н. ОГУРЕЕВА. 1999. Зоны и типЫ поясности растительности России и сопредельных территорий. М 1:8 000000. Пояснительный текст и легенда к карте - [Zones and altitudinal zonality types of vegetation of Russia and adjacent territories. Scale 1:8 000000 . Explanatory text and legend to the map] М., МГУ [Moscow, $\mathrm{MSU}$, $64 \mathrm{pp}$.

[SCHLJAKOV, R.N. \& N.A. KONSTANTINOVA] ШЛЯКOB P.H., H.A. КОНСТАНТИНОВА. 1982. Конспект флоры мохообразных Мурманской области. - [Synopsis of the Bryophytes of the Murmansk Region] Anamumbl [Apatity], 222 pp.

SMYKLA, J., J. WOIEK \& A. BARCIKOWSKI. 2007. Zonation of vegetation related to penguin rookeries on King George Island, Maritime Antarctic. - Arctic, Antarctic, and Alpine Research 39(1): 143-151.

[TATARINKOVA, I.P.] TATAРИНКОВА И.П. 1967. О влиянии птиц на растительность острова Большого Айнова (Западный Мурман)
- [About bird influence on vegetation on the Bolshoi Ainov Island, the Western Murman Coast]. В кн.: Структура и функииональнобиогеоценотическая роль животного населения суши. Материалы совещания (23-24 февраля 1967, Москва) М., МОИП [In: Struktura i funkcional'no-biogenoticheskaja rol' zhivotnogo naselenija sushi. (23-24 February 1967, Moscow) Moscow, Moscow Society of Naturalists]: 111-112.

[TATARINKOVA, I.P.] TAТАРИНКОВА И.П. 1970. Трофические связи больших морских и серебристых чаек - доминирующих видов биоценоза Айновых островов (Западный Мурман). - [Food chain of great black-backed gulls and herring gulls, as dominant species of the Ainov Islands biocenosis, the Western Murman Coast]. В кн.: Продуктивность биоченозов Субарктики. Материалы симпозиума по изучению, рациональному использованию и охране воспроизводимых ресурсов Крайнего Севера СССР. Свердловск, АН СССР [In: Produktivnost' biocenozov Subarktiki. Proceedings of the symposium on the study, management and conservation of reproducible resources of the Far North of the USSR. Sverdlovsk, Academy of Science of the USSR]: 175-176.

[TATARINKOVA, I.P.] ТАТАРИНКОВА И.П. 1975. Количественная характеристика экскреторной деятельности крупных чаек и влияние ее на растительность. - [The quantitative description of excretory activity of large gulls and its influence on the vegetation $] B \kappa н$.: Роль животных в функционировании экосистем. Материаль совешания. М., Наука [In: Rol' zhivotnyh v funkcionirovanii ekosistem. Proceedings of the workshop, Moscow, Nauka]: 107-110.

[TATARINKOVA, I.P.] TATAРИНКОВА И.П. 2011. О некоторых факторах, определяющих размещение гнёзд гаги Somateria mollissima по стациям на Айновых островах. - [About some determining factors of nest location for station of the common eider Somateria mollissima on the Ainov Islands] Русский орнитологический журнал [Russskij ornitologicheskij zhurnal] 20(678): 1558-1561.

[TATARINKOVA, I.P., R.G. CHEMYAKIN, E.I. KHLEBOSOLOV \& O.A. KHLEBOSOLOVA] ТATAРИНКОВА, И.П., Р.Г. ЧЕМЯКИН, Е.И. ХЛЕБОСОЛОВ, О.А. ХЛЕБОСОЛОВА. 2007. Формирование гнездовой колонии серых гусей Anser anser на Айновых островах Баренцева моря. - [The formation of nesting colony of of the greylag goose Anser anser on the Ainov Islands of the Barents Sea] Русский орнитологический журнал [Russskij ornitologicheskij zhurnal] 16(347): 263-269.

VIDAL, E., F. MEDAIL, T. TATONI, P. VIDAL \& R. ROCHE. 1998. Functional analysis of the newly established plants induced by nesting gulls on Riou archipelago (Marseille, France). - Acta Oecologica 19(3): 241-250.

WAIT, D.A., D.P. AUBREY \& W.B. ANDERSON. 2005. Seabird guano influences on desert islands: soil chemistry and herbaceous species richness and productivity. - Journal of Arid Environments 60(4): 681-695.

[YAKOVLEV, В.А.] ЯКОВЛЕВ, Б.А. 1961. Климат Мурманской области. - [Climate of the Murmansk Province] Мурманск [Murmansk], 99 pp. 